\title{
Sedative Filling
}

National Cancer Institute

\section{Source}

National Cancer Institute. Sedative Filling. NCI Thesaurus. Code C62295.

A restoration intended to relieve pain. 